\title{
The Relationship between Parenting Style and Children's Emotional Development among Indonesian Population
}

\author{
LIA M. BOEDIMAN, SELLINA DESNAWATI \\ Fakultas Psikologi, Universitas Indonesia \\ Email: 1boediman72@gmail.com
}

\begin{abstract}
The current research investigated the relationship between parenting style and emotional regulation among children in Indonesian population. A total of 126 parents of children aged between 3 and 6 years old participated in this study. The Parenting Styles and Dimensions Questionnaire Short Version (Robinson, Mandleco, Olsen, \& Hart, 2001) was used to measure parents' parenting style, and the Emotion Regulation Checklist (Shields \& Cicchetti, 1997) was used to measure parents' perceptions of children's emotional regulation. The results revealed that there was a positive significant relationship between authoritative parenting style and the development of children's emotional regulation, and there were negative significant relationships between authoritarian and permissive parenting styles and children's emotional regulation in this population. This suggests that authoritative style of parenting provides the best support for the development of emotional regulation among children in an Indonesian population.
\end{abstract}

\section{Keywords: parenting; parenting style; emotional regulation}

\begin{abstract}
Abstrak: Penelitian ini menyelidiki hubungan antara gaya pengasuhan orang tua dengan regulasi emosi pada anak-anak di Indonesia. Sebanyak 126 orang tua dengan anak berusia antara 3 sampai 6 tahun berpartisipasi dalam penelitian ini. Parenting Styles and Dimensions Questionnaire Short Version (Robinson, Mandleco, Olsen, \& Hart, 2001) digunakan untuk mengukur gaya pengasuhan orang tua dan emotion Regulation Checklist (Shields \& Cicchetti, 1997) digunakan untuk mengukur persepsi orang tua terhadap regulasi emosi anak. Hasil penelitian menunjukkan bahwa terdapat hubungan positif yang signifikan antara gaya pengasuhan otoritatif dengan perkembangan regulasi emosi anak, dan terdapat hubungan negatif yang signifikan antara gaya pengasuhan otoritarian dan permisif dengan perkembangan regulasi emosi pada anak. Hal ini menunjukkan bahwa gaya pengasuhan otoritatif memberikan dukungan yang paling baik untuk perkembangan regulasi emosi pada anak pada populasi di Indonesia.
\end{abstract}

Kata kunci: pola asuh; gaya pengasuhan; regulasi emosi

\section{INTRODUCTION}

Emotional regulation is the ability to regulate emotions in order to function adaptively and optimally in the environment (Shields \& Cicchetti, 1997). Denham (1998), indicated that the first five years of life is crucial in developing healthy emotional development. The ability to regulate emotions is an important predictor of healthy development in children. Children who are able to regulate their emotions tend to do well psychologically, socially, and academically (Morris, Silk, Steinberg, Myers, \& Robinson, 2007). These children are able to form close friendships and engage in positive interactions with peers (Shonkoff \& Phillips, 2000), adapt more easily in new environments, and cope better with stress (Feng, Shaw, Kovacs, Lane, O'Rourke, \& Alarcon, 2008). These children are also better able to pay attention, work hard, and excel in school. On the other hand, children with poor emotional regulation tend to exhibit behavioral problems, develop mental health issues, and have social and academic difficulties (Buschgens, Aken, Swinkels, Ormel, Verhulst, \& Butelaar, 2010).

Emotional regulation in children does not develop automatically. Early in life, young children require large amounts of support and guidance from parents to regulate their emotions. Through supportive interaction with parents, children learn how to cope better with 
uncomfortable situations and overwhelming feelings (Jabeen, Anis-ul-Haque, \& Riaz, 2013; Cole, Dennis, Smith-Simon, \& Cohen, 2009; Morris at al. 2007). This type of interaction shapes and nurtures the development of positive emotional regulation in children (Dennis, 2006).

It is uncontentious to state that parents play an important role in nurturing the development of emotional regulation in children. However, parents differ in their styles of interacting with their children and different parenting styles influence how they parenting their children (Darling \& Steinberg, 1993). Parenting style is a pattern of attitudes that underlie the emotional tones of how parents behave and interact with their children (Darling \& Steinberg, 1993). Baumrind (1991), identified three distinct styles of parenting that can be understood based on their levels of demandingness and responsiveness. Demandingness refers to the expectations and disciplines that parents place on their children to ensure children behave appropriately. Responsiveness refers to the nurturance and support that parents provide to promote individuality and independence in their children (Pasquali, Gouveia, Silva dos Santos, Nunes da Fonseca, \& Moura de Andrade, 2012).

These three types of parenting style are: 1) authoritarian; 2) authoritative; 3) indulgent (permissive) (Baumrind, 1966). Authoritarian parenting is characterized by strict, controlling, demanding, and punitive types of parenting with little warmth and support. Children with authoritarian parents tend to have difficulty in trusting others and to be unsatisfied with their lives (Baumrind, 1971). The authoritative parents are the type of parents who provide a balance between placing realistic limits and controls with support, warmth, and nurturance. Children with authoritative parents tend to be self-reliant, responsible, assertive, and explorative (Baumrind, 1971). Indulgent/permissive parenting refers to the type of parents who are loving and highly involved in their children's lives but place no restriction, expectation, rules, or controls on their children. Children with permissive parents tend to be dependent, lacking in self-control, irresponsible, and display aggressive behavior (Baumrind, 1971).

Numerous studies conducted in Western cultures on parenting style have indicated that children with authoritative parents tend to be well functioning (psychologically, socially, and academically) (Steinberg, Lamborn, Dornbusch, \& Darling, 1992; Steinberg, Lamborn, \& Darling, 1994; Shumow, Vandell, \& Posner, 1998; Amato \& Fowler, 2002; Fletcher, Walls, Cook, \& Madison, 2008; Williams et al., 2009; Rinaldi $\&$ Howe, 2012). On the other hand, children with authoritarian parents tend to be highly obedient and conform to their parents' rules and expectations. These children tend to have low self-confidence, be dependent on others (Baumrind, 1971; Lamborn, Mounts, Steinberg, \& Dornbusch, 1991) and display behavioral problems (Buschgens et al., 2010). Children with indulgent/permissive parents tend to have good social skills and selfconfidence but display behavioral misconduct and engage in drug and alcohol use (Baumrind, 1991; Lamborn, Mounts, Steinberg, \& Dornbusch, 1991; Fletcher, Walls, Cook, \& Madison, 2008). Based on these Western-based studies, it can be concluded that authoritative parenting provides the most positive and optimal outcome for child emotional regulation and adaptation (Areepattamannil, 2010; Rinaldi \& Howe, 2012; Fletcher, Walls, Cook, \& Madison, 2008; Steinberg, Lamborn, Dornbusch, \& Darling, 1992; Amato \& Fowler, 2002).

A growing number of studies have been conducted on parenting styles and children's emotional regulation in non-Western cultures, but with mixed results. $\mathrm{C}$ a Studies were conducted on parenting styles and teenagers' emotional regulation in Asian and Arab populations found that authoritarian parenting provided a more positive influence on children compared to authoritative and permissive parenting (Chao, 1994; Chao, 2000; Dwairy, Achoui, Abouserie, Farah, Shjleh, Fayed, \& Khan, 2006). In these cultures, children associated parents with a more authoritarian style of parenting as more caring, attentive, and supportive. However, Jabeen et al. (2013), 
found a positive relationship between authoritative parenting style and emotional regulation in teenagers in Pakistan. This implies that parents who apply an authoritative style of parenting tend to have children with positive emotional regulation skills. On the contrary, there is a positive relationship between authoritative styles of parenting and emotional regulation skills in these teenagers, consistent with findings from Western cultures.

The study of parenting style and emotional regulation in children in nonWestern cultures has revealed mixed results. Further, most of the study in non-Western cultures focused more on adolescents, rather than on young children, even though it is revealed that the first five years of life is very crucial time for nurturing healthy emotional regulation in children. In addition, there has not been any study done that specifically investigate the relationship between parenting style and the development of emotional regulation in young children in an Indonesian population. Thus, this study sought to investigate the relationship of parenting style and emotional regulation in children, and to identify which parenting style best support the development of positive emotional regulation among Indonesian population: authoritarian, authoritative, or permissive parenting.

In this study, the researchers predicted that:

1. There will be a positive relationship between an authoritative style of parenting and emotional regulation in children.

2. There will be a negative relationship between an authoritarian style of parenting and emotional regulation in children.

3. There will be a negative relationship between an indulgent/permissive style of parenting and emotional regulation in children.

\section{METHOD}

Participant. Participants in this study were 126 parents of children aged between 3 and 6 years old (120 mothers, 6 fathers). $80.15 \%$ from participants were aged between 20 and 40 years, $14.3 \%$ between 41 and 65 years, and
$5.56 \%$ did not identify their age. The participants' levels of education consisted of: high school (31\%), bachelor's degree $(23 \%)$, associate degree (21.5\%), middle school (11.9\%), elementary school (7.9\%), doctoral degree $(2.4 \%)$, and master's degree (1.6\%). The majority of participants were Javanese $(n=51$, $40.5 \%)$, Betawi $(n=33,26.2 \%)$ and Sundanese $(n=26,20.2 \%)$. The participants were recruited from several schools, government child development centers (Pos Pelayanan Terpadu), religious communities, and University settings in the urban, Jabotabek area.

Procedure. The procedure of the study involved the following steps: 1) Pilot of the written questionnaires to ensure they could be easily understood by participants. This was completed by individuals with similar characteristics to the sample in the main study; 2) Revision of the questionnaires based on the pilot data; 3) Run reliability test on the parenting style and children's emotional regulation questionnaires to ensure their reliability. After the questionnaires were validated, the researchers created a booklet that contained all of the questionnaires. The data was distributed to participants who meet the study's criteria around Jabotabek area through snowballing method.

Measuring Instrument. There are three measuring instruments used in this study, Family Background Questionnaire, Parenting Styles and Dimensions Questionnaires (PSDQ) short version, and Emotion Regulation Checklist (ERC).

Family Background Questionnaire was used to gather information about participants' background. It obtains information including age, religion, ethnicity, education, financial status, and employment details (Sanders \& Morawska, 2010).

Parenting Styles and Dimensions Questionnaires (PSDQ) - short version was used to measure the styles of parenting (Robinson et al., 2001). The PSDQ - short version is frequently used instrument in studying parenting styles internationally (Kern \& Jonyniene, 2012). The PSDQ - short version is an parenting styles instrument that measure 
global typologies that is based on Baumrind's dimensions but also to examine specific parenting practice apply within each parenting style (Robinson et al., 1995). The questionnaire consists of a total of 32 items divided as follows: 15 items measuring an authoritative style of parenting, 12 items measuring an authoritarian style of parenting, and 5 items measuring a permissive style of parenting. The authoritative style's items consist of three subfactors (connection, regulation and autonomy granting). The authoritarian style's items also consist of three sub-factors (physical coercion, verbal hostility and non-reasoning). The permissive style's items consist of one subfactor (indulgent). This is a Likert-scale measure that is anchored from 1 to $5(1=$ never, $2=$ sometimes, $3=$ seldom, $4=$ sometimes, and $5=$ always). Each participants will have overall mean score on authoritative, authoritarian and permissive parenting style. Within each parenting style, participants will also have a mean score on different sub-factor. The highest mean score of the sub-factors from each parenting style indicated which parenting practice that the participants tend to use in how they interact with their children. Further, the higher mean score on one of the parenting styles indicate the participants' parenting style tendency or preference (Robinson et al., 1995; Kern and Jonyniene, 2012). The PSDQ has good internal reliability. The authoritarian parenting style subscale has a reliability coefficient of $\boldsymbol{\alpha}=0.82$, the authoritative parenting style subscale has a reliability coefficient of $\boldsymbol{\alpha}=0.86$, and the permissive parenting style subscale has a reliability coefficient of $\boldsymbol{\alpha}=0.64$.

Emotion Regulation Checklist (ERC) was used to measure parents' perceptions of children's behavior (Shields \& Cicchetti, 1997). The ERC consists of 24 items and two subscales: lability/negativity and emotion regulation. There are 16 items on the subscale for lability/negativity and there are 8 items on the sub-scale for emotion regulation. This checklist used Likert-scale style with criteria from 1 to $4(1=$ almost always, $2=$ often, $3=$ sometimes, and $4=$ never), with 13 items being reverse scored. The mean of all items is calculated, and a higher score indicates good emotional regulation whereas a lower score indicates poor emotional regulation. The reliability for the ERC is considered adequate $(\boldsymbol{\alpha}=0.69)$.

Data Analysis. Statistical analyses were conducted on participants' demographic as well as questionnaire data consisting of the following steps:

1. Descriptive analyses: statistical information relating to demographic information such as age, ethnicity, religion, and education was calculated.

2. Assessment of the normal distribution of pilot data: this was conducted to evaluate whether the sample represents the population.

3. Pearson product moment correlations: these were selected to analyze the data as the variables were continuous and there was a linear relationship between them (Cohen \& Swerdlik, 2010).

\section{RESULT}

Parenting Style. Parenting style was evaluated based on the score of the means, standard deviations, and minimum and maximum scores for each factor. The minimum score that can be obtained for each subscale is 1 and the maximum score is 5 . There is no single or total score on PSDQ, but only the score from each subscale. The means and standard deviation are displayed in Table 1.

Table 1. Descriptive statistics for parenting style

\begin{tabular}{lcccc}
\hline Factor & $\boldsymbol{M}$ & $\boldsymbol{S D}$ & Min & Max \\
\hline Authoritative & 3.96 & .53 & 2.31 & 4.88 \\
Authoritarian & 2.13 & .46 & 1.00 & 3.17 \\
Permissive & 2.64 & .55 & 1.20 & 3.60 \\
\hline
\end{tabular}

Based on the mean scores, the authoritative style of parenting was higher than the authoritarian and permissive styles of parenting. There was a difference of 1.83 between the mean scores for authoritative and 
authoritarian parenting, and .51 difference between the scores for authoritative and permissive parenting. There were 60 participants who scored below the mean, and 66 participants who scored above the mean. The results show that the majority of parents in this study adopted an authoritative style of parenting.

Children's Emotional Regulation. The Emotion Regulation Checklist (ERC) was used to measure parents' perceptions of their children's emotional regulation skills. The mean score, standard deviation, and the minimum and maximum scores were used. The ERC consists of two subscales, emotion regulation and liability/negativity, but produces a single score that indicates children's level of emotional regulation.

Table 2. Descriptive statistics for children's emotional regulation

\begin{tabular}{lllll}
\hline & $M$ & $S D$ & $\begin{array}{l}\text { Minimu } \\
\mathrm{m}\end{array}$ & $\begin{array}{l}\text { Maximu } \\
\mathrm{m}\end{array}$ \\
\hline $\begin{array}{l}\text { Emotional } \\
\text { Regulatio }\end{array}$ & $\begin{array}{l}3.0 \\
\mathrm{n}\end{array}$ & $\begin{array}{l}.2 \\
9\end{array}$ & 2.42 & 3.75 \\
\hline
\end{tabular}

The highest score that can be obtained from the ERC is 4. The mean value obtained was $\mathrm{M}=3.04$, the majority of the children had high scores, meaning that Indonesian parents perceived their children to have already acquired relatively good emotional regulation.

The Relationship between Parenting Style and Children's Emotional Regulation. The correlation analyses indicated that: 1) there was a significant positive relationship between an authoritative parenting style and children's emotional regulation $(r=+.40, n=126, p<.01$, one tailed); 2) there was a significant negative relationship between an authoritarian style of parenting with children's emotional regulation ( $r=-.42, n=126, p<.01$, one tailed); 3 ) there was a significant negative relationship between a permissive style of parenting with children's emotional regulation ( $r=-.29, n=126, p<.01$, one tailed). Based on this, it can be interpreted that the more parents utilized the characteristics of an authoritative style of parenting, the better children's ability to regulate their emotions. On the other hand, the more parents utilized the characteristics of an authoritarian style of parenting, the lower children's ability was to regulate their emotions. In addition, parents with a permissive style of parenting also tended to have children with poorer emotional regulation.

Table 3. Relationships between parenting style and children's emotional regulation

\begin{tabular}{llc}
\hline & & $\begin{array}{c}\text { Emotional } \\
\text { Regulation }\end{array}$ \\
\hline \multirow{4}{*}{ Authoritative } & $\begin{array}{l}\text { Pearson } \\
\text { Correlation }\end{array}$ & 0.4 \\
& Sig. (1-tailed) & 0 \\
Authoritarian & $\begin{array}{l}\text { Pearson } \\
\text { Correlation }\end{array}$ & 0.42 \\
& Sig. (1-tailed) & 0 \\
Permissive & $\begin{array}{l}\text { Pearson } \\
\text { Correlation }\end{array}$ & -0.29 \\
& Sig. (1-tailed) & 0 \\
\hline
\end{tabular}

We also explored whether parents' education might contribute to the results using ANOVA and present the findings in Table 4.

Table 4. ANOVA on the general view of parenting style and education

\begin{tabular}{lcc}
\hline & $F$ & Sig. \\
\hline Total Authoritative & 6.71 & 0.00 \\
Total Authoritarian & 2.13 & 0.07 \\
Total Permissive & 0.81 & 0.54 \\
\hline
\end{tabular}

ANOVA was conducted to test whether parenting style had a significant relationship with parents' level of education. An authoritative parenting style $(F=6.71)$ had a significant relationship with parents' level of education $(p<0.01)$. Tukey's HSD results indicated that the significant relationship only occurred for parents with a bachelor level of education compared with parents with elementary education ( $p=.002)$; parents with secondary education $(p=.000)$; and parents with high school education ( $p=.005)$. Tukey's HSD was also conducted for parents' education at masters and doctoral levels but no significant relationships were identified.

DISCUSSION 
We evaluated whether there is a relationship between parenting style and young children's emotional regulation in an Indonesian culture. There was a significant positive relationship between authoritative parenting style and children's emotional regulation, and there was a significant negative relationship between authoritarian and permissive parenting styles and children's emotional regulation. These findings are consistent with the research done by Jabeen et al., (2013) who found that an authoritative style of parenting has a positive correlation with children's emotional regulation, and authoritarian and permissive styles of parenting are negatively correlated with children's emotional regulation. This implies that authoritarian and permissive parents tend to have children lacking in the ability to control their emotion and behavior. This is also consistent with Cheng et al. (in Jabeen, Anisus-Haque, \& Riyaz, 2013), who found that permissive parenting correlated with children's levels of aggression and lack of self-control.

Although the results of this study are consistent with Cheng et al (in Jabeen, Anis-usHaque, \& Riyaz, 2013), other studies in Arab and Asian cultures indicated that authoritarian parenting provides a positive influence (Chao, 1994; Chao, 2000; Dwairy et al. 2006). In Asian cultures (including Indonesia), authoritarian parenting might be associated with parental attention, care, love, and support. However, this study revealed that the majority of Indonesian parents adopt an authoritative style of parenting, a parenting style that is most often adopted by parents in Western cultures. This type of parenting differs from the values that most Indonesian parents are accustomed to. Thus, to further investigate this finding, we extended the analysis to test whether there was another variable that could explain these results. The results showed that parents' level of education influences their parenting style. Parents with bachelor degree levels of education tended to utilize an authoritative style of parenting compared to parents with lower levels of education. It is also assumed that parents with masters and doctoral levels of education might have adopted an authoritative parenting style. However, due to the small number parents with master or doctoral levels of education, the results did not reveal a significant relationship between these higher levels of education and children's emotional regulation.

Every culture has different values and rules that help determine what behavior is considered appropriate and inappropriate. These values and rules also determine how individuals function adaptively and optimally in their cultures. Thus, the ability to regulate emotion is also tied to cultural values. The ERC focused on a Western perspective of how individuals should function. Indonesian people might have different views in regard to individual functioning, and, thus, might have different definitions of emotional regulation. Considering this factor, future research should use measures that are more appropriate for Indonesian population and take into consideration the importance of cultural values.

The spread of the participants demographic/background in this study was scattered, thus, further analysis of the data was not feasible. For future research, it is recommended that the participants are more evenly distributed in terms of their backgrounds including gender, age, employment, and ethnicity, so that more extensive analysis of these factors can be conducted.

\section{REFERENCES}

Amato, P. R., \& Fowler, F. (2002). Parenting practices, child adjustment, and family diversity. Journal of Marriage and Family, 64, 703-716.

Baumrind, D. (1966). Effects of authoritative parental control on child behavior. Child Development, 37, 887-907.

Baumrind, D. (1971). Current patterns of parental authority. Developmental Psychology, 4, 1-103.

Baumrind, D. (1991). The parenting style influence on adolescent competence and substance use. The Journal of Early Adolescence, 11, 56-95.

Buschgens, C. M., Van Aken, M. G., Swinkels, S. N., Ormel, J., Verhulst, F., \& 
Buitelaar, J. (2010). Externalizing behaviors in preadolescents: Familial risk to externalizing behaviors and perceived parenting styles. European Child \& Adolescent Psychiatry, 19(7), 567-575.

Chao, R. K. (1994). Beyond parental control and authoritarian parenting style: understanding Chinese parenting through the cultural notion of training. Child Development, 65, 1111-1119.

Chao, R. K. (2000). The parenting of immigrant Chinese and European American mothers: Relations between parenting styles, socialization goals, and parental practices. Journal of Applied Developmental Psychology, 21, 233-248.

Cohen, R. J., \& Swerdlik, M. E. (2010). Psychological testing and assessment (7th Ed.). Boston: McGraw-Hill.

Cole, P. M., Dennis, T. A., Smith-Simon, K. E., \& Cohen, L. H. (2009). Preschoolers' emotion regulation strategy understanding: Relations with emotion socialization and child selfregulation. Social Development, 18 (2), 324-352.

Darling, N., \& Steinberg, L. (1993). Parenting style as context: An integrative model. Psychological Bulletin, 113(3), 487496. Retrieved from http://www.oberlin.edu/faculty/ndarli ng/lab/psychbull.pdf

Dwairy, M., Achoui, M., Farah, A., Sakhleh, A., Fayad , M., \& Khan, H. K. (2006). Journal Cross-Culture Psychology, 37, 230-247

Fletcher, A. C., Walls, J. K., Cook, E. C., \& Madison, K. J. (2008). Parenting style as a moderator of associations between maternal disciplinary strategies and child well-being. Journal of Family Issues, 29, 1724.

Jabeen, F., Anis-ul-Haque, M., \& Riaz, M. N. (2013). Parenting styles as predictors of emotion regulation among adolescents. Pakistan Journal of Psychological Research, 28(1), 25105. Retrieved from http://www.pjprnip.edu.pk/pjpr/index. $\mathrm{php/pjpr/article/view/298}$

Kern, R. M., \& Jonyniene, J. (2012). Psychometric properties of the Lithuanian version of the parenting style and dimensions questionnaire (PSDQ): Pilot study. The Family Journal Counseling and Therapy for Couples dan Families, 20(2), 205-214.

Lamborn, S. D., Mounts, N. S., Steinberg, L., \& Dornbusch, S. M. (1991). Patterns of competence and adjustment among adolescents from authoritative, authoritarian, indulgent, and neglectful families. Child Development, 62, 1049-1065.

Morris, A. S., Silk, J. S., Steinberg, L., Myers, S. S., \& Robinson, L. R. (2007). The role of the family context in the development of emotion regulation. Social Development, 16(2), 361-388.

Pasquali, L., Gouveia, V. V., Silva dos Santos, W., Nunes da Fonsêca, P. , \& Moura de Andrade, J. (2012). Perceptions of parents questionnaire: Evidence for a measure of parenting styles. Paidéia, 22(52), 155-164.

Rinaldi, C. M., \& Howe, N. (2012). Mothers' and fathers' parenting styles and associations with toddlers' externalizing, internalizing, and adaptive behaviors. Early Childhood Research Quarterly, 27, 266-273.

Robinson, C. C., Mandleco, B., Olsen, S. F., \& Hart, C. H. (2001). The parenting styles and dimensions questionnaire (PSDQ). Handbook of Family Measurement Techniques, 3, 319-321.

Sanders, M. R., \& Morawska, A. (2010). Family background questionnaire (FBQ). Brisbane, Australia: Parenting and Family Support Centre.

Shields, A., \& Cicchetti, D. (1997). Emotion regulation among school-age children: The development and validation of a new criterion Q-sort scale. Developmental Psychology, 33(6), 906-916. Retrieved from https://www.ncbi.nlm.nih.gov/pubme d/9383613 
Shonkoff, J. P., \& Phillips, D. A. (2000). From neurons to neighborhoods: The science of early childhood development. Washington, D.C: National Academy Press.

Shumow, L., Vandell, D. L., \& Posner, J. K. (1998). Harsh, firm, and permissive parenting in low- income families: Relations to children's academic achievement and behavioral adjustment. Journal of Family Issues, 19, 483-507.

Steinberg, L., Lamborn, S. D., Dornbusch, S. M., \& Darling, N. (1992). Impact of Parenting Practices on Adolescent Achievement: Authoritative Parenting, School Involvement, and Encouragement to Succeed. Child Development, 63(5), 1266-1281.

Steinberg, L., Lamborn, S. D., \& Darling, N. (1994). Over-time changes in adjustment and competence among adolescents from authoritative, authoritarian, indulgent, and neglectful families. Child Development, 65, 754.

Tanyel, N. E. (2009). Emotional regulation: Developing toddlers' social competence. Early Childhood Dimensions, 37(2), 10-15. Retrieved from http://www.southernearlychildhood.or g/upload/pdf/Emotional_Regulation_ Developing_Toddlers_Social_Compet ence_Nur_E_Tanyel_Vol_37_No_2.p df.

Williams, L. R., Degnan, K. A., Perez-edgar, K. E., Henderson, H. A., Rubin, K. H., Pine, D. S., Steinberg, L., \& Fox, N. A. (2009). Impact of behavioral inhibition and parenting style on internalizing and externalizing problems from early childhood through adolescence. Journal of Abnormal Child Psychology, 37(8), 1063-1075. 